\title{
Spesialisasi Industri Auditor Sebagai Prediktor Earnings Response Coefficient Perusahaan Publik yang Terdaftar di Bursa Efek Indonesia
}

\author{
Hans Hananto Andreas \\ Fakultas Ekonomika dan Bisnis Universitas Kristen Satya Wacana, Salatiga \\ Email: hanshananto2@yahoo.co.id
}

\begin{abstract}
ABSTRAK
Penelitian ini menguji pengaruh spesialisasi industri auditor pada ERC pada perusahaan publik yang terdaftar di BEI periode pengamatan 2006-2010. Tujuan dari riset ini adalah melihat hubungan kualitias audit yang diproksikan dengan auditor spesialisasi industri dengan kualitas informasi, yang dapat dilihat dari ERC. Pengujian hipotesis menggunakan model regresi berganda. Sampel diambil dengan menggunakan tehnik purposive dan didapat 134 perusahaan publik yang terdaftar di Bursa Efek Indonesia. Penelitian ini menemukan bahwa spesialisasi industri auditor berpengaruh positif pada Earnings Response Coefficient (ERC). Perusahaan yang menggunakan auditor spesialisasi industri memiliki ERC pada lebih tinggi dibandingkan ERC pada perusahaan yang tidak menggunakan auditor spesialisasi industri.
\end{abstract}

Kata kunci: Earnings Response Coefficient (ERC), spesialisasi industri auditor, kualitas audit.

\begin{abstract}
This study investigates the effect of auditor's industry specialisation on the ERC of public companies listed on the BEI in the period of 2006-2010. The purpose of this study is to examine the relationship between audit quality as proxied by auditor's industry specialisation and the earnings information quality as measured by ERC. Hypothesis testing was conducted using multiple linear regression technique. Using purposive sampling technique, 134 public companies listed on the BEI were selected as the sample of this study. This study finds that there is a positive relationship between auditor's industry specialisation and company's ERC. The ERC of companies that use auditors with industry specialisation is higher than ERC of companies that do not use auditors with industry specialisation.
\end{abstract}

Keywords: Earnings Response Coefficient (ERC), auditor industry specialization, audit quality.

\section{PENDAHULUAN}

Informasi sangat penting bagi investor dalam pengambilan keputusan investasi. Perusahaanperusahaan publik yang terdaftar di Bursa Efek Indonesia diwajibkan melapor laporan keuangan secara berkala sebagai salah satu sumber informasi bagi investor dan pengambilan keputusan investasi para pelaku pasar. Salah satu informasi yang disajikan adalah pengumuman yang berhubungan dengan laba, karena informasi laba ini digunakan oleh investor serta memberikan gambaran mengenai kinerja suatu perusahaan.
Penelitian untuk mengetahui apakah informasi keuangan, khususnya informasi laba mempunyai nilai yang relevan bagi para pengambil keputusan investasi (value relevance), dimulai dari Ball and Brown (1968), investor menemukan bahwa laba akuntansi memiliki kandungan informasi yang relevan.Penelitian mengenai hubungan laba dengan nilai pasar saham juga dilakukan oleh Beaver (1968), bahwa investor menghubungan laba dengan nilai pasar saham untuk mengetahui kandungan informasi dalam pengumuman laba tahunan. Penelitian tersebut mengemukakan bahwa pengumuman laba akuntansi berhubungan 
dengan harga saham, sehingga laba akuntansi memiliki relevansi nilai terhadap nilai pasar saham dan dapat digunakan oleh investor untuk pengambilan keputusan bisnis.

Penelitian mengenai value relevance informasi laba dilakukan dengan cara menghubungkan data akuntansi yaitu laba dengan data pasar modal (saham). Beberapa penelitian dibangun untuk mengetahui seberapa sensitif harga saham terhadap perubahan laba akuntansi dan apakah tingkat sensitivitas ini berbeda antar perusahaan. Apabila laba dan return memiliki hubungan, maka laba dikatakan memiliki kandungan informasi (Setyaningtyas, 2009). Penelitian mengenai penilaian hubungan antara laba dan harga saham seringkali berfokus pada koefisien respon laba, karena koefisien ini dianggap sebagai pengukur sensitifitas dari return ekuitas terhadap laba kejutan (Setyaningtyas, 2009). Penelitian model ini dikenal dengan penelitian Earnings Responses Coefficient atau disingkat ERC.

\section{Earnings Responses Coefficient (ERC)}

Ekawati (2008) mendefinisikan ERC sebagai kuat lemahnya reaksi pasar terhadap pengumuman laba, sehingga dapat digunakan untuk memprediksi kandungan informasi laba yang dihasilkan oleh laporan laba. Menurut Zulhwati (2005), ERC adalah reaksi atas laba yang diumumkan perusahaan. Reaksi yang diberikan tergantung dari kualitas earning yang dihasilkan perusahaan.

Beberapa penelitian berikut ini menunjukkan bahwa ada beberapa faktor atau determinan yang mempengaruhi ERC. Penelitian yang dilakukan oleh Imhoff dan Lobo (1992) melihat reaksi harga saham terhadap laba kejutan berhubungan dengan kualitas angka earnings yang dilaporkan. Penelitian mereka menunjukkan bahwa perusahaan yang memiliki konsensus rendah dengan ramalan earnings analis cenderung memiliki ERC rendah. Easton and Zmijewsji (1989) menemukan bahwa ukuran perusahaan berkolerasi dengan ERC. Christina (2005) menyatakan bahwa potensi laba berhubungan positif dengan ERC. Lang and McNichols (1990) menggunakan korelasi antara arus kas dengan earnings sebagai proksi untuk kualitas laporan earnings.Sebagai perluasan dari pernyataan tersebut, dikatakan bahwa auditor yang berkualitas tinggi memberikan kepastian yang besar terhadap kesesuaian laporan keuangan. Oleh karena itu, diharapkan adanya korelasi yang tinggi antara expected future cash flow, earnings akuntansi dengan auditor yang berkualitas tinggi (Mayangsari 2004). Collins and Kothari (1989) menunjukkan bahwa perusahaan yang memiliki kesempatan bertumbuh yang lebih besar akan memiliki ERC yang tinggi serta earnings yang berhubungan negatif dengan ERC.

Asumsi yang mendasari penelitian ini adalah bahwa investor merespon secara berbeda informasi laba akuntansi yang berbeda sesuai dengan kualitas informasi laba tersebut. Semakin berkualitas laba akuntansi maka semakin tinggi respon investor.Keputusan ekonomi yang dibuat oleh pelaku pasar berdasarkan informasi yang diperoleh dari laporan keuangan biasanya tercermin dalam tindakan pelaku pasar yang disebut reaksi pasar.Karena investor tidak dapat secara langsung melihat hal-hal yang mendasari nilai earnings yang sesungguhnya, maka mereka pada umumnya bergantung pada angka-angka akuntansi yang dilaporkan. Untuk meningkatkan kredibilitas earnings yang dilaporkan, investor biasanya bergantung pada opini auditor eksternal yang memberikan jasa atestasi tentang kesesuaian earnings yang dilaporkan sesuai dengan prinsip akuntansi berterima umum (Mayangsari 2004). Tujuan dari penelitian ini adalah untuk mengetahui pengaruh kualitas audit dengan kualitas informasi yang dihasilkan dari jasa auditor berkualitas (spesialisasi industri auditor), dalam hal laporan keuangan khususnya earnings, yang dilihat dari besarnya ERC, serta untuk melihat pengaruh spesialisasi industri auditor pada besarnya ERC perusahaan yang menggunakan auditor spesialisasi industri dan non spesialisasi industri.

Penelitian-penelitian sekarang telah berkembang dengan pengujian variabel yang berpengaruh terhadap ERC yaitu spesialisasi industri auditor (Mayangsari 2004). Auditor berperan penting dalam memberikan pendapat mengenai laporan keuangan perusahaan yang disusun sesuai dengan prinsip akuntansi berterima umum, karena opini auditor dalam laporan keuangan (seperti kualitas earnings perusahaan) cenderung direaksi oleh pelaku pasar sebagai signal dalam pengambilan keputusan ekonomi (Netralia 2007). Kualitas auditor memiliki pengaruh yang besar terhadap kualitas earnings yang dilaporkan, karena investor beranggapan bahwa laporan earnings dari auditor yang berkualitas lebih akurat dan dapat mencerminkan nilai ekonomi yang sesungguhnya (Teoh and Wong, 1993). Craswell et al. (1995) menunjukkan bahwa spesialisasi auditor pada bidang tertentu merupakan dimensi lain dari kualitas audit. Spesialisasi industri membuat auditor mampu menawarkan kualitas audit yang lebih tinggi dibandingkan dengan yang tidak spesialis (Hogan and Jeter, 1999). Hasil penelitian dari Mayangsari (2004) menyatakan bahwa spesialisasi industri auditor mempengaruhi ERC. 
Auditor memiliki fungsi sebagai pihak yang memberikan kepastian terhadap integritas angkaangka akuntansi yang dihasilkan di dalam laporan keuangan.Pengetahuan yang harus dimiliki oleh auditor tidak hanya pengetahuan mengenai pengauditan dan akuntansi, melainkan juga industri klien. Meskipun mengaudit perusahaan manufaktur prinsipnya sama dengan mengaudit perusahaan asuransi, namun sifat bisnis, prinsip akuntansi, sistem akuntansi, dan peraturan perpajakan yang berlaku mungkin berbeda, sehingga hal ini mengharuskan auditor memiliki pengetahuan mengenai karakteristik industri tertentu yang mempengaruhi pengauditan. Kondisi ini menunjukkan adanya kebutuhan terhadap spesialisasi auditor (Kusharyanti 2003).

Auditor dikatakan spesialisasi industri jika auditor memiliki banyak klien dalam industri yang sama. Auditor spesialis indutri diukur dengan cara yang digunakan oleh Craswell et al. (1995). Pertama, sampel industri yang digunakan adalah indutri yang minimal memiliki 30 perusahaan. Kedua, auditor dikatakan spesialis jika auditor tersebut mengaudit $15 \%$ dari total perusahaan yang ada dalam industri tersebut. Sedangkan penelitian dari Zhou dan Elder (2001) mendefinisikan KAP sebagai spesialisasi industri jika mengaudit lebih dari $10 \%$ perusahaan dari total perusahaan yang ada dalam suatu industri.

Penelitian mengenai tuntutan atas kualitas audit dapat dijelaskan dengan agency theory (teori keagenan). Teori keagenan merupakan proses kontrak antara dua orang atau lebih dan masingmasing pihak yang terlibat dalam kontrak mencoba mendapatkan yang terbaik bagi dirinya (Scott 2000). Pemilik dan agen diasumsikan sebagai pihak yang memiliki pengetahuan di bidang ekonomi secara rasional dan saling memiliki kepentingan pribadi. Karena agen dan prinsipal memiliki kepentingan pribadi, maka akan timbul masalah jika terdapat informasi yang asimetri (information asymetry). Scott (2000) menyatakan apabila beberapa pihak yang terkait dalam transaksi bisnis lebih memiliki informasi daripada pihak lainnya, maka kondisi tersebut dikatakan sebagai asimetri informasi. Asimetri informasi dapat diartikan sebagai informasi yang terdistribusi dengan tidak merata diantara agen dan pemilik, serta tidak mungkinnya pemilik untuk mengamati secara langsung usaha yang dilakukan oleh agen. Hal ini menyebabkan agen cenderung melakukan perilaku yang tidak semestinya (disfunctional behaviour). Salah satu disfunctional behaviour yang dilakukan agen adalah pemanipulasian data dalam laporan keuangan. Auditor adalah pihak yang dianggap mampu menjem- batani kepentingan pihak prinsipal (shareholders) dengan pihak manajer (agen) dalam mengelola keuangan perusahaan.Auditor melakukan fungsi monitoring pekerjaan manajer melalui sebuah sarana yaitu laporan tahunan perusahaan, dan memberikan opini atas laporan keuangan tersebut mengenai kewajarannya.

Teori keagenan lebih lanjut dapat diperluas dengan audit brand name dan spesialisasi industri sebagai suatu fungsi peningkatan kos agensi (Mayangsari 2004). Penelitian-penelitian sebelumnya (Craswell et al. 1995, Hogan and Jeter 1999) menunjukkan bahwa variasi cross-sectional faktorfaktor khusus perusahaan dapat mempengaruhi kos agensi, sehingga perbedaan ini membutuhkan keahlian tertentu yang bias mendeteksi lebih baik. Dengan demikian, kondisi ini menunjukkan adanya kebutuhan terhadap spesialisasi auditor. Craswell et al. (1995) menunjukkan bahwa spesialisasi auditor dalam bidang tertentu merupakan dimensi lain dari kualitas audit. Hasil penelitiannya menunjukan bahwa fee auditor spesialis lebih tinggi dibandingkan fee auditor non spesialis. Hogan and Jeter (1999) mengungkapkan bahwa spesialisasi industri membuat auditor mampu menawarkan kualitas audit yang lebih tinggi dibandingkan yang tidak spesialis. Hal ini ditunjukkan dengan adanya peningkatan pangsa pasar pada kantor-kantor akuntan yang memiliki spesialisasi dari tahun pengamatan 1976 sampai dengan 1993.

Beberapa penelitian berikut ini menguji pengaruh persepsi kualitas auditor terhadap earning responses coefficient. Teoh and Wong (1993) menunjukkan bahwa pasar merespon secara berbeda terhadap kualitas auditor, yang diproksikan dengan auditor Big 5 dan non-Big 5.Artinya, semakin berkualitas auditor maka semakin tinggi kredibilitas angka-angka akuntansi yang dilaporkan, sehingga dengan demikian semakin besar ERC nya. Tetapi sejak merebak kasus Enron yang melibatkan kantor akuntan publik Arthur Anderson, maka penelitian-penelitian yang menggunakan proksi Big 5 dan non-Big 5 mulai mendapat kritikan dan menimbulkan keraguan. Kemudian penelitian berkembang menggunakan proksi audit yang lebih baik yaitu spesialisasi industri auditor. Hogan and Jetter (1999) menunjukkan bahwa spesialisasi industri auditor merupakan dimensi lain dari kualitas audit. Mereka menyatakan bahwa spesialisasi industri membuat auditor mampu menawarkan kualitas audit yang lebih tinggi dibandingkan yang tidak spesialis. Balsam et al. (2003) menemukan bahwa spesialisasi industri auditor dapat meningkatkan ERC. Dunn et al. (2000) juga menemukan bahwa klien yang diaudit oleh auditor spesialisasi industri memiliki 
kualitas pengungkapan yang tinggi. Spesialisasi industri auditor berhubungan positif dengan kualitas audit karena auditor yang berpengalaman mengaudit klien pada industri khusus lebih mempunyai kemampuan untuk mengidentifikasi masalah industri khusus daripada auditor yang belum berpengalaman mengaudit industri khusus, Kantor Akuntan Publik yang mempunyai banyak klien dalam industri yang sama (spesialisasi pada industri tertentu) akan lebih memahami risiko audit khas yang ada dalam industri khusus tersebut.

Dari uraian di atas dapat dirumuskan hipotesis 1 yaitu:

H1: Spesialisasi industri auditor berpengaruh positif pada ERC

Hasil penelitian Mayangsari (2004) mendukung hipotesis bahwa spesialisasi industri auditor mempengaruhi ERC. Dikatakan ERC perusahaan yang diaudit oleh auditor spesialisasi industri lebih besar dari ERC perusahaan yang diaudit oleh auditor non spesialisasi industri. Balsam et al. (2003) menemukan juga bahwa spesialisasi industri auditor dapat meningkatkan ERC. Pelaku pasar merespon positif perusahaan yang diaudit oleh spesialisasi industri auditor dalam hal kredibilitas pengungkapan laba. Spesialisasi industri auditor memberikan signal lebih kredibel dan kemudian laba dengan presisi yang lebih baik. Laba dengan presisi lebih baik terkait dengan kualitas earnings.Secara intuitif besarnya ERC mencerminkan kualitas eanings yang tinggi.

Penelitian dari Gramling et al. (2001) menunjukkan bahwa penggunaan auditor spesialisasi industri dapat mengetahui adanya earnings manajemen, kesalahan prediksi dan kemampuan untuk memprediksi arus kas mendatang.Demikian juga penelitian dari Becker et al. (1998) yang menjelaskan bahwa dengan adanya auditor spesialisasi industri dapat mendeteksi earnings manajemen karena auditor spesialis memiliki pengetahuan lebih (superior knowledge) dan tindakan untuk mencegah terjadinya earnings manajemen demi reputasi mereka, sehingga dapat meningkatkan kualitas laba.Gramling et al. (2001) membuktikan bahwa laba perusahaan yang diaudit oleh auditor spesialisasi industri mempunyai daya prediksi arus kas mendatang yang lebih akurat dibandingkan dengan auditor non spesialisasi industri. Dengan demikian semakin spesialis auditor maka hal tersebut akan direspon berbeda oleh investor. Auditor spesialisasi industri akan lebih memahami mengenai seluk beluk industri, masalah-masalah yang muncul, serta risiko audit khas yang ada di dalam industri tersebut. Sehingga semakin berkualitas auditor, dalam hal ini semakin spesialis, maka semakin tinggi kredibilitas angka-angka akuntansi yang dilaporkan. Hal tersebut menunjukkan bahwa auditor spesialis dapat meningkatkan kualitas earnings yang dilaporkan, sehingga dapat meningkatkan ERC. Dari uraian diatas maka dapat dirumuskan hipotesis 2 sebagai berikut:

H2: ERC pada perusahaan yang menggunakan auditor spesialisasi industri lebih tinggi dibandingkan ERC pada perusahaan yang tidak menggunakan auditor spesialisasi industri.

Penelitian ini menguji kembali temuan dari Mayangsari (2004) dengan menambahkan satu hipotesis dari penelitian sebelumnya yaitu apakah spesialisasi industri auditor berpengaruh terhadap ERC. Di dalam penelitian ini menggunakan perhitungan ERC yang dilakukan oleh Chandrarin (2003), serta menambahkan satu variabel kontrol yaitu konservatisme akuntansi, karena penelitian yang dilakukan oleh Suaryana (2007) yang menguji hubungan antara ERC dengan konservatisme akuntansi didapat hasil bahwa ERC perusahaan yang menerapkan akuntansi konservatif lebih rendah daripada perusahaan tidak menerapkan akuntansi konservatif. Penerapkan akuntansi konservatif akan menghasilkan laba yang berfluktuasi dan prediktibilitas laba yang rendah. Laba yang memiliki daya prediksi rendah kurang bermanfaat dalam memprediksi laba masa depan sehingga ERC yang dihasilkan akan rendah (Lipe 1990).

\section{METODE PENELITIAN}

Populasi dan sampel dalam penelitian ini adalah perusahaan-perusahaan publik yang terdaftar di Bursa Efek Indonesia (BEI) tahun 20062010. Pemilihan sampel dilakukan dengan metode purposive sampling, dengan kriteriaadalah: 1). Perusahaan publik yang digunakan adalah perusahaan publik yang tidak teregulasi karena perbedaan karakteristik industri (regulasi dan non regulasi) mempengaruhi ERC. Hal ini sesuai dengan penelitian Teets and Wasley (1996) bahwa ERC perusahaan yang non regulasi lebih besar dibandingkan ERC perusahaan yang teregulasi. 2). Ukuran spesialisasi industri menggunakan klasifikasi kelompok industri besar yang memiliki sub industri lebih dari 30 perusahaan, sesuai dengan penelitian Craswell et al. (1995). 3). Perusahaan yang menerbitkan laporan keuangan secara lengkap untuk menentukan nilai ERC masing-masing perusahaan selama 5 tahun pengamatan, sedangkan informasi mengenai data auditor independen akan dipakai sebagai pengamatan pada tahun 2010 . 
Data yang digunakan merupakan data sekunder yang diperoleh dari Indonesia Capital Market Directory yang meliputi data auditor independen atau kantor akuntan publik yang memenuhi syarat dan terdaftar di BEI tahun 2010, selanjutnya diklasifikasi menjadi auditor spesialis dan non spesialis. Pengkasifikasian ini didasarkan pada prosentase jumlah perusahaan yang diaudit oleh auditor dalam suatu industri. Penelitian dari Zhou and Elder (2001) mendefinisikan KAP sebagai spesialisasi industri jika mengaudit lebih dari $10 \%$ perusahaan dari total perusahaan yang ada dalam industri yang sama. Data laporan keuangan meliputi laporan laba rugi, nilai buku ekuitas, laporan arus kas operasi, depresiasi, kapitalisasi pasar, dan nilai pasar ekuitas tahun 2006-2010, serta data IHSG (selama periode jendela 3 hari sebelum dan 3 hari sesudah tanggal pengumuman laba tahunan), harga saham penutupan harian untuk setiap sampel perusahaan yang memenuhi syarat dan terdaftar di BEI tahun 2006-2010.

\section{Pemilihan dan Pengukuran Variabel}

Variabel dependen dalam penelitian ini adalah Earnings Response Coefficient (ERC). ERC adalah reaksi atas laba yang diumumkan perusahaan. ERC merupakan koefisien yang diperoleh dari regresi proksi harga saham dan laba akuntansi.Proksi harga saham yang digunakan adalah cumulative abnormal return (CAR), sedangkan proksi laba akuntansi adalah unexpected earnings (UE). (Zulhwati 2005). Besarnya ERC diperoleh dengan melakukan beberapa tahap perhitungan, sesuai dengan penelitian yang dilakukan oleh Chandrarin (2003). Tahap pertama menghitung cumulative abnormal return (CAR) masing-masing sampel dan tahap kedua menghitung unexpected earnigns sampel.

Cumulative abnormal return (CAR) adalah proksi harga saham yang menunjukkan besarnya respon pasar terhadap laba akuntansi yang dipublikasikan (Mayangsari 2004). Penelitian ini menggunakan market adjusted model. Model ini menganggap bahwa penduga yang terbaik untuk mengestimasi return sekuritas adalah return pasar pada saat peristiwa. Market adjustedmodel digunakan karena pasar modal di Indonesia memiliki nilai dan volume transaksi perdagangan yang relatif sedikit. Harga saham di bursa cenderung bergerak pada hari-hari atau peristiwa tertentu saja. Sehingga dalam menggunakan market adjusted model tidak akan ditemui kesulitan dikarenakan perdagangan disekitar hari pengumuman cenderung lebih banyak (Junaedi 2005). Market Adjusted Model menganalisis ab- normal return kumulatif disekitar tanggal pengumuman laporan keuangan tahunan. Penelitian ini menggunakan periode jendela selama 7 hari yaitu 3 hari sebelum dan 3 hari sesudah pengumuman laporan keuangan.

Abnormal return harian dalam penelitian ini dihitung dengan menggunakan market adjusted model dengan rumus:

$\mathrm{AR}_{\mathrm{it}}=\mathrm{R}_{\mathrm{it}}-\mathrm{RM}_{\mathrm{it}}$

di mana:

$\mathrm{AR}_{\mathrm{it}}=$ return tidak normal saham ke $\mathrm{i}$ pada hari ke t

$\mathrm{R}_{\mathrm{it}}=$ return saham ke i pada periode hari ke $\mathrm{t}$

$\mathrm{RM}_{\text {it }}=$ return pasar ke i pada hari ke $\mathrm{t}$

Sedangkan untuk return saham harian diukur dengan rumus:

$\mathrm{R}_{\mathrm{it}}=\left(\mathrm{P}_{\mathrm{it}}-\mathrm{P}_{\mathrm{it}-1}\right) / \mathrm{P}_{\mathrm{it}-1}$

di mana:

$\mathrm{R}_{\mathrm{it}}=$ return saham $\mathrm{i}$ pada periode hari ke $\mathrm{t}$

$\mathrm{P}_{\mathrm{it}}=$ harga penutupan saham i pada hari ket

$\mathrm{P}_{\mathrm{it}-1}=$ harga penutupan saham $\mathrm{i}$ pada hari $\mathrm{t}-1$

Return pasar $\left(\mathrm{RM}_{\mathrm{it}}\right)$ dihitung dengan rumus:

$\mathrm{RM}_{\text {it }}=\left(\mathrm{IHSG}_{\text {it }}-\mathrm{IHSG}_{\mathrm{it}-1}\right) / \mathrm{IHSG}_{\mathrm{it}-1}$

di mana:

$\mathrm{RM}_{\mathrm{it}}=$ return pasar i pada perioda hari ke $\mathrm{t}$

$\mathrm{IHSG}_{\text {it }}=$ indeks harga saham gabugan pada hari ke $\mathrm{t}$

$\mathrm{IHSG}_{\mathrm{it}-1}=$ indeks harga saham gabungan pada hari t-1

CAR diperoleh dengan cara menjumlahkan return tidak normal perusahaan i sepanjang periode jendela. Penggunaan periode jendela pendek karena investor akan bereaksi dengan cepat terhadap informasi yang memiliki nilai ekonomis. CAR selama periode jendela dihitung dengan rumus:

$\mathrm{CAR}=\sum \mathrm{AR}_{\text {it }}$

di mana:

$\mathrm{CAR}_{\text {it }}=$ return tidak normal kumulatif saham perusahaan i selama periode jendela 3 hari sebelum dan 3 hari sesudah tanggal pengumuman laba tahunan

$\mathrm{AR}_{\text {it }}=$ return tidak normal saham ke i selama periode jendela

Sedangkan untuk unexpected earnings (UE) diukur dengan menggunakan pengukuran yang dilakukan oleh Hartono (2000), yaitu:

$\mathrm{UE}_{\mathrm{it}}=\left(\mathrm{E}_{\mathrm{it}}-\mathrm{E}_{\mathrm{it}-1}\right) / \mathrm{E}_{\mathrm{it}-1}$

di mana:

$\mathrm{UE}_{\mathrm{it}}=$ Unexpected earnings perusahaan $\mathrm{i}$ pada periode $\mathrm{t}$

$\mathrm{E}_{\mathrm{it}}=$ Laba akuntansi perusahaan $\mathrm{i}$ pada periode $\mathrm{t}$ 
$\mathrm{E}_{\mathrm{it}-1}=$ Laba akuntansi perusahaan i pada periode tahun sebelumnya (t-1).

Variabel independen yang digunakan dalam penelitian ini adalah spesialisasi industri auditor. Variabel ini diukur dengan menggunakan variabel dummy, yaitu 1 untuk auditor spesialis dan 0 untuk auditor non spesialis. Auditor spesialis diukur dengan cara yang digunakan oleh Zhou and Elder (2001) dalam mendefinisikan KAP sebagai spesialisasi industri jika mengaudit lebih dari 10\% dari total perusahaan yang ada dalam industri yang sama.

Variabel kontrol adalah variabel yang dikendalikan atau dibuat konstan sehingga hubungan variabel bebas terhadap variabel terikat tidak dipengaruhi oleh faktor luar yang tidak diteliti (Widhiarso 2011). Variabel kontrol yang digunakan di dalam penelitian ini antara lain:

1) Persistensi laba

Persistensi laba merupakan cerminan kualitas laba yang diperoleh perusahaan karena perusahaan dapat mempertahankan perolehan laba tersebut dari waktu ke waktu (Mayangsari, 2004). Penelitian sebelumnya yang dilakukan oleh Kormendi and Lipe (1987), Easton and Zmijweski (1989) menunjukkan bahwa persistensi laba berhubungan positif dengan ERC. Perhitungan persistensi laba diukur dari slope regresi atas perbedaan laba saat ini dengan laba sebelumnya karena sesuai dengan kondisi Indonesia (Chandrarin, 2003), yaitu:

$\mathrm{X}_{\mathrm{it}}=\alpha+B \mathrm{X}_{\mathrm{it}-1}+\varepsilon$

di mana:

$\mathrm{X}_{\mathrm{it}}=$ laba perusahaan $\mathrm{i}$ tahun $\mathrm{t}$

$\mathrm{X}_{\mathrm{it}-\mathrm{1}}=$ laba perusahaan $\mathrm{i}$ tahun $\mathrm{t}-1$

2) Pertumbuhan Perusahaan

Pertumbuhan perusahaan adalah kemampuan perusahaan yang lebih dalam mengeksploitasi kesempatan mengambil laba dibandingkan dengan perusahaan yang setara dalam kelompok industri. Variabel ini diukur dari market to book ratio masing-masing perusahaan pada periode akhir laporan keuangan (Mulyani 2007) dengan rumus:

Market to book ratio $=$ nilai pasar ekuitas/nilai buku ekuitas

3) Struktur Modal

Perusahaan yang memiliki tingkat leverage yang tinggi berarti memiliki hutang yang lebih besar dibandingkan modal. Dengan demikian jika terjadi peningkatan laba maka yang diuntungkan adalah debtholders, sehingga semakin baik kondisi laba perusahaan maka semakin negatif respon pemegang saham, karena pemegang saham beranggapan bahwa laba tersebut hanya menguntungkan kreditur (Mayangsari 2004). Untuk mengukur struktur modal menggunakan rumus dari Dhaliwal et al. (1991) dan Kim et al. (2000) yaitu:

$\mathrm{Lev}$ it $=\mathrm{TU}_{\text {it }} / \mathrm{TA}_{\text {it }}$

di mana:

$\mathrm{TU}=$ Total hutang perusahaan $\mathrm{i}$ pada tahun $\mathrm{t}$

$\mathrm{TA}=$ Total asset perusahaan $\mathrm{i}$ pada tahun $\mathrm{t}$

4) Ukuran Perusahaan

Perusahaan besar dianggap memiliki informasi yang lebih banyak dibandingkan perusahaan kecil. Konsekuensinya, semakin informatif harga saham, maka semakin kecil muatan informasi earnings sekarang (Mayangsari 2004). Besaran perusahaan diukur dengan log natural total asset menurut penelitian dari Collins and Kothari (1989).

5) Konservatisme Akuntansi

Penelitian yang dilakukan oleh Suaryana (2007) yang menguji hubungan antara ERC dengan konservatisme akuntansi didapat hasil bahwa ERC perusahaan yang menerapkan akuntansi konservatif lebih rendah daripada perusahaan tidak menerapkan akuntansi konservatif. Penerapkan akuntansi konservatif akan menghasilkan laba yang berfluktuasi dan prediktibilitas laba yang rendah. Laba yang memiliki daya prediksi rendah kurang bermanfaat dalam memprediksi laba masa depan sehingga ERC yang dihasilkan akan rendah (Lipe 1990). Assegaf (2008) kembali menguji pengaruh konservatisme laporan keuangan dengan ERC dengan menambah sejumlah variabel kontrol dan menggunakan pengujian yang berbeda. Penelitian tersebut menunjukkan bahwa konservatisme berhubungan positif tidak signifikan terhadap earnings response coefficient. Pengukuran konservatisme akuntansi dalam penelitian ini menggunakan model Givoly and Hyan (2000) yang mengukur konservatisme dengan cara mengurangkan income before extraordinary item dengan arus kas operasi dan ditambahkan dengan beban depresiasi. Rumus dari pengukuran konservatisme yang dilakukan oleh Givoly and Hyan adalah: $\mathrm{KA}_{\text {it }}=\mathrm{NI}_{\text {it }}-\mathrm{CFO}_{\text {it }}$

di mana:

$\mathrm{KA}_{\text {it }}=$ tingkat konservatisme perusahaan $\mathrm{i}$ pada tahun $\mathrm{t}$

$\mathrm{NI}_{\mathrm{it}}=$ Laba sebelum extraordinary item ditambah dengan depresiasi dari perusahaan i pada tahun $\mathrm{t}$

$\mathrm{CFO}_{\text {it }}=$ cash flow dari kegiatan operasi untuk perusahaan i pada tahun $\mathrm{t}$

Selanjutnya hasil perhitungan KA tersebut dikalikan dengan -1, sehingga semakin tinggi nilai KA menunjukkan konservatisme yang semakin tinggi. 


\section{Teknik dan Langkah Analisis}

Tehnik analisis yang digunakan dalam penelitian ini adalah analisis regresi berganda, serta melakukan uji asumsi klasik dengan uji normalitas, autokorelasi, heteroskedasititas, dan multikolinearitas. Tingkat kepercayaan yang digunakan adalah $95 \%$.

\section{Uji Hipotesis}

\section{Hipotesis 1}

Model yang digunakan dalam penelitian ini mengacu kepada Chandrarin (2003) dalam menentukan earnings response coefficient masingmasing sampel, yaitu:

$\mathrm{CAR}_{\mathrm{it}}=\mathrm{\alpha}_{0}+\mathrm{\alpha}_{1} \mathrm{UE}_{\mathrm{it}}+\varepsilon$

di mana:

$\mathrm{CAR}_{\text {it }}=$ Cumulative abnormal return perusahaan i

$\mathrm{UE}_{\mathrm{it}}=$ Unexpected earnings

$\varepsilon \quad=$ Komponen error

Untuk pengujian hipotesis 1 dilakukan dengan regresi berganda dengan persamaan regresi:

$$
\begin{aligned}
& \mathrm{ERC}=B_{0}+B_{1} D_{\mathrm{it}}+B_{2} \mathrm{PERS}_{\mathrm{it}}+B_{3} \mathrm{MB}_{\mathrm{it}}+B_{4} \mathrm{LEV}_{\mathrm{it}}+ \\
& B_{5} \mathrm{LMV}_{\text {it }}+B_{6} \mathrm{KA}_{\mathrm{it}}+\varepsilon \\
& \text { di mana: } \\
& \text { ERC = Earnings Response Coefficient } \\
& \mathrm{D}_{\text {it }} \quad=\text { variabel dummy yaitu } 1 \text { untuk audi- } \\
& \text { tor spesialis, dan } 0 \text { untuk auditor non } \\
& \text { spesialis } \\
& \text { PERS }_{\text {it }}=\text { persistensi laba akuntansi } \\
& \mathrm{MB}_{\text {it }}=\text { market value dibagi book value, seba- } \\
& \text { gai proksi pertumbuhan } \\
& \mathrm{LEV}_{\text {it }}=\text { struktur modal } \\
& \mathrm{LMV}_{\text {it }}=\log \text { natural dari total asset } \\
& \mathrm{KA}_{\mathrm{it}}=\text { konservatisme akuntansi } \\
& B=\text { koefisien regresi } \\
& \varepsilon=\text { error }
\end{aligned}
$$

2. Hipotesis 2

Hipotesis 2 diuji dengan menggunakan independent t-test.uji beda independent t-test digunakan untuk menentukan apakah dua sampel tersebut memiliki rata-rata yang berbeda. Uji bedaindependent $t$-test dilakukan dengan cara membandingkan perbedaan antara dua nilai rata-rata dengan standar error dari perbedaan rata-rata dua sampel (Ghozali 2008). Analisa dilakukan dengan melihat besarnya nilai rata-rata dari independent $t$-test dan ERC antara perusahaan yang menggunakan auditor spesialisasi industri dan auditor non spesialisasi industri.

$\mathrm{CAR}_{\mathrm{S}}=\mathrm{\alpha}_{0}+\mathrm{\alpha}_{1} \mathrm{UE}_{\mathrm{it}}+\varepsilon$

di mana:

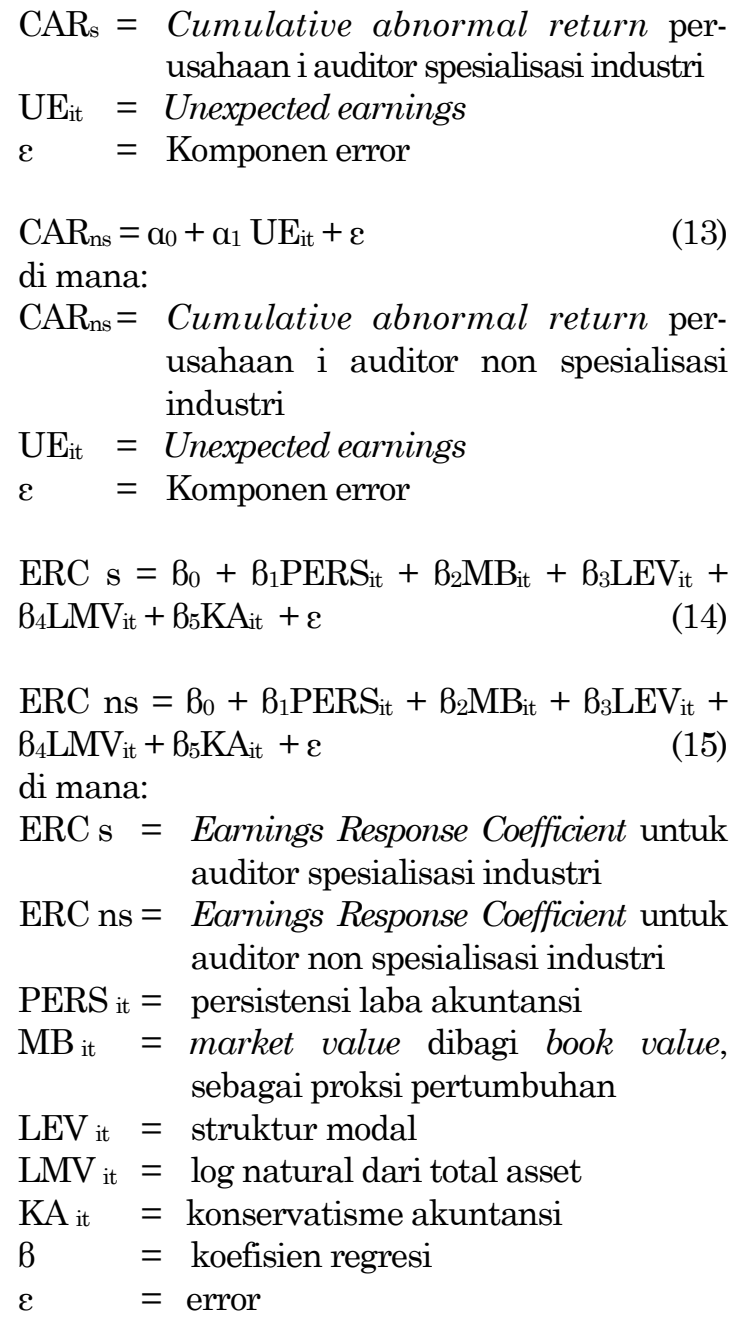

\section{HASIL PENELITIAN DAN PEMBAHASAN}

\section{Statistik Deskriptif}

Jumlah sampel sebanyak 134 didapat nilai minimum untuk ERC sebesar -0,11 dan nilai maksimum sebesar 0,10 dengan rata-rata 0,0007. Nilai rata-rata ERC yang cenderung rendah menunjukkan bahwa informasi laba direaksi kecil oleh pasar (Mulyani 2007). Hal ini juga sejalan dengan penelitian yang dilakukan oleh Chandrarin (2003) yang mendapatkan nilai ERC sebesar 0,02. Nilai ERC yang kecil menunjukkan bahwa dalam pengambilan keputusan ekonomi, para pelaku bisnis membutuhkan informasi tentang kondisi dan kinerja keuangan perusahaan, namun informasi tersebut tidak hanya berdasarkan pada informasi laba saja tetapi banyak informasiinformasi lainnya (Chandrarin 2003).

Data untuk auditor didapat bahwa ada 56 perusahaan atau 42 persen menggunakan auditor spesialisasi industri, sedangkan sisanya 78 perusahaan atau 58 persen tidak menggunakan auditor spesialisasi industri. Hal ini menunjukkan 
bahwa secara keseluruhan dari total sampel, perusahaan lebih menggunakan auditor non spesialisasi industri dari pada auditor spesialisasi industry. Pada Tabel 1 disajikan statistik deskriptif untuk variabel-variabel yang diteliti.

Tabel 1. Statistik Deskriptif

\begin{tabular}{|c|c|c|c|c|}
\hline & $\mathbf{N}$ & Min. & Mean $_{1}$ & $\begin{array}{c}\text { Std. } \\
\text { Deviation }\end{array}$ \\
\hline Erc & 134 & -.11 & .0007 & .03855 \\
\hline $\begin{array}{l}\text { Struktur } \\
\text { modal }\end{array}$ & 134 & .04 & .5165 & .20251 \\
\hline Ukuran Psh & 134 & 23.46 & 31.0227 .4443 & 1.49512 \\
\hline $\begin{array}{l}\text { Persisten } \\
\text { laba }\end{array}$ & 134 & -8.67 & 25.65 & 3.75295 \\
\hline Pertumb pers & 134 & -1.15 & $4.49 \quad 1.3190$ & 1.05435 \\
\hline Konservatif & 134 & 17.81 & 28.3224 .4188 & 1.92693 \\
\hline \multirow{3}{*}{\multicolumn{2}{|c|}{\begin{tabular}{l}
\multicolumn{1}{c}{ Ketarangan } \\
Auditor Spesialis \\
Auditor Non- \\
Spesialis
\end{tabular}}} & Dummy Jumlah & \multirow{2}{*}{\multicolumn{2}{|c|}{$\begin{array}{c}\text { Prosentase } \\
42 \%\end{array}$}} \\
\hline & & 1 & 4 & \\
\hline & & 0 & \multicolumn{2}{|c|}{$58 \%$} \\
\hline
\end{tabular}

Sumber: Data Olahan

\section{Pengujian Asumsi Klasik}

1) Uji Normalitas Residual

Pengujian normalitas dalam penelitian ini, menggunakan uji Kormogorov Smirnov test dengan nilai $\alpha=0,05$. Hasil uji normalitas dapat dilihat dalam Tabel 2.

Tabel 2. Uji Normalitas: Kolmogorov-Smirnov Test

\begin{tabular}{lc}
\hline & Unstandardized Residual \\
\hline $\mathrm{N}$ & 134 \\
Mean & 0,00000 \\
Standar Deviation & 0,03653 \\
Positive & 0,059 \\
Negative & $-0,090$ \\
Kolmogorov-Smirnov Z & 1,042 \\
Asymp. Sig (2-tailed) & 0,228 \\
\hline
\end{tabular}

Sumber: Data olahan

Hasil uji normalitas dengan menggunakan Kormogorov Smirnov test menunjukkan tingkat signifikansi sebesar 0,228. Angka ini lebih besar dari nilai $\alpha=0,05$, maka dapat disimpulkan bahwa model regresi yang digunakan telah terdistribusi secara normal.

2) Uji Autokorelasi

Tabel 3. Uji Autokorelasi

\begin{tabular}{ccccc}
\hline R & R square & $\begin{array}{c}\text { Adj R } \\
\text { Square }\end{array}$ & Std. Error & $\begin{array}{c}\text { Durbin- } \\
\text { Watson }\end{array}$ \\
\hline 0,319 & 0,102 & 0,059 & 0,03739 & 2,000 \\
\hline
\end{tabular}

Sumber: Data olahan
Hasil uji Autokorelasi (Tabel 3) menunjukkan nilai Durbin-Watson sebesar 2,000. Nilai ini akan dibandingkan dengan nilai yang ada dalam DW tabel dengan sampel pengamatan (n) sebanyak 134 dan jumlah variabel independen (k) sebanyak 6. Nilai dalam tabel DW menunjukkan bahwa DU < DW < 4-DU yaitu, $1,812<2,000<2,187$ maka dapat disimpulkan bahwa dalam model regresi tidak terdapat masalah autokorelasi.

3) Uji Heteroskedatisitas

Tabel 4. Uji Heterokedastisitas

\begin{tabular}{lrc}
\hline \multicolumn{1}{c}{ Model } & \multicolumn{1}{c}{ t } & Sig. \\
\hline (constant) & $-0,199$ & 0,843 \\
Dummy & $-0,348$ & 0,728 \\
Strukmodal & 0,857 & 0,393 \\
Ukuran pers & $-0,467$ & 0,641 \\
Persistenlb & $-0,404$ & 0,687 \\
Pertumbuhpers & $-0,510$ & 0,611 \\
Konservatif & 1,547 & 0,124 \\
\hline
\end{tabular}

Sumber: Data olahan

Pengujian Heteroskedatisitas pada penelitian ini menggunakan Uji Glejser yang ditunjukkan pada Tabel 4. Hasil pengujian menunjukkan seluruh variabel bebas tidak berpengaruh pada nilai absolute residual yang terlihat dari nilai signifikansi masing-masing variabel bebas di atas 0,05 . Hal ini berarti model regresi bebas dari heteroskedastisitas.

4) Uji Multikolinearitas

Berdasarkan hasil pengujian yang dilakukan, tidak ada nilai tolerance yang kurang dari 0,1 dan nilai variance inflation factor (VIF) menunjukkan tidak ada nilai yang lebih dari 10 sehingga dapat disimpulkan bahwa tidak terdapat multikolinearitas.

Tabel 5. Uji Multikolinearitas

\begin{tabular}{lcc}
\hline \multicolumn{1}{c}{ Model } & Tolerance & VIF \\
\hline (constant) & & \\
Dummy & 0,813 & 1,229 \\
Strukmodal & 0,963 & 1,038 \\
Ukuran pers & 0,590 & 1,694 \\
Persistenlb & 0,902 & 1,109 \\
Pertumbuhpers & 0,845 & 1,183 \\
Konservatif & 0,574 & 1,742 \\
\hline
\end{tabular}

Sumber: Data olahan

\section{Hasil Analisis dan Pengujian Hipotesis}

Berdasarkan Tabel 6 dapat dilihat bahwa nilai adjusted $\mathrm{R}^{2}$ adalah sebesar 0,059 atau 5,9 persen. Hal ini menunjukkan bahwa variabel bebas spesialisasi industri auditor, struktur modal, konservatif akuntansi, persistensi laba, per- 
tumbuhan perusahaan dan ukuran perusahaan mempengaruhi secara bersama-sama variabel terikat ERC sebesar 5,9 persen sedangkan sisanya 94,1 persen dipengaruhi oleh variabel lain yang tidak dimasukkan di dalam model. Meskipun nilai adjusted $\mathrm{R}^{2}$ rendah, tetapi dengan nilai $\mathrm{F}$ test sebesar 2,398 dengan signifikan 0,031, bahwa angka signifikansi 0,031 lebih kecil dari 0,05 mengindikasikan bahwa model yang digunakan dalam penelitian ini layak.

Tabel 6. Analisis Hasil

\begin{tabular}{lcrc}
\hline \multicolumn{1}{c}{ Model } & $\begin{array}{c}\text { Unstandardized } \\
\text { Coefficients }\end{array}$ & $\mathbf{t}$ & Sig. \\
\hline (constant) & 0,026 & 0,390 & 0,697 \\
Dummy & 0,015 & 2,055 & 0,042 \\
Strukmodal & $-0,022$ & $-1,362$ & 0,176 \\
Ukuran pers & 0,001 & 0,398 & 0,692 \\
Persistenlb & $-0,003$ & $-3,192$ & 0,002 \\
Pertumbuhpers & $-0,001$ & $-0,429$ & 0,668 \\
Konservatif & $-0,002$ & $-0,846$ & 0,399 \\
\hline Adjusted $\mathrm{R}^{2}=0,059 ;$ F-test $=2,398 ;$ & Sig. F $=0,031$ \\
\hline
\end{tabular}

Sumber: Data olahan

Dilihat dari Tabel 6 maka dapat disusun persamaan regresi linier berganda dalam sebagai berikut:

$\mathrm{ERC}=0,026+0,015 \mathrm{D}-0,022 \mathrm{SM}-0,002 \mathrm{KA}-$

$$
0,003 \mathrm{PL}-0,001 \mathrm{PP}+0,001 \mathrm{UP}+\varepsilon
$$

Hipotesis 1 menguji apakah spesialisasi industri auditor berpengaruh pada ERC. Nilai signifikansi sebesar 0,042 lebih kecil dari nilai $\alpha=$ 0,05 berarti $\mathrm{Ha}$ diterima. Ini berarti auditor spesialisasi industri berpengaruh terhadap ERC.

Hasil penelitian ini konsisten dengan penelitian dari Balsam et al. (2003), bahwa pelaku pasar merespon positif perusahaan yang diaudit oleh auditor spesialisasi industri dalam hal kredibilitas pengungkapan laba. Hasil penelitian ini juga konsisten dengan penelitian yang dilakukan oleh Penelitian dari Gramling et al. (2001) menunjukkan bahwa penggunaan auditor spesialisasi industri dapat mengetahui adanya earnings manajemen, kesalahan prediksi dan kemampuan untuk memprediksi arus kas mendatang. Demikian juga penelitian dari Becker et al. (1998) yang menjelaskan bahwa dengan adanya auditor spesialisasi industri dapat mendeteksi earnings manajemen karena auditor spesialis memiliki pengetahuan lebih (superior knowledge) dan tindakan untuk mencegah terjadinya earnings manajemen demi reputasi mereka, sehingga dapat meningkatkan kualitas laba.Penelitian dari Gramling et al. (2001) membuktikan bahwa laba perusahaan yang diaudit oleh auditor spesialisasi industri mempunyai daya prediksi arus kas mendatang yang lebih akurat dibandingkan dengan auditor non spesialisasi industri.
Hasil pengujian hipotesis 2 ditunjukkan dalam Tabel 7 dan 8. Hipotesis 2 menguji apakah ERC pada perusahaan yang menggunakan auditor spesialisasi industri lebih tinggi dari pada ERC perusahaan yang menggunakan auditor non spesialisasi industri. Pengujian dilakukan dengan melihat nilai ERC antara perusahaan yang menggunakan auditor spesialisasi industri dan auditor non spesialisasi industri, dan setelah itu dilakukan uji beda independent $t$-test.

Tabel 7. Hasil Olahan Auditor Nonspesialis Industri

\begin{tabular}{lcc}
\hline & \multicolumn{2}{c}{ Model } \\
\cline { 2 - 3 } & (Constant) & UE \\
\hline UnstandardizedCoefficients: & & \\
B & 0,042 & 0,000 \\
Std. Error & 0,017 & 0,001 \\
StandardizedCoefficients: & & \\
B & & $-0,042$ \\
t & 2,455 & $-0,423$ \\
Sig & 0,016 & 0,673 \\
\hline
\end{tabular}

Sumber: Data olahan

Tabel 8. Hasil Olahan Auditor Spesialis Industri

\begin{tabular}{lrc}
\hline & \multicolumn{2}{c}{ Model } \\
\cline { 2 - 3 } & (Constant) & UE \\
\hline UnstandardizedCoefficients: & & \\
B & 0,042 & 0,000 \\
Std. Error & 0,017 & 0,001 \\
StandardizedCoefficients: & & \\
B & & $-0,042$ \\
t & 2,455 & $-0,423$ \\
Sig & 0,016 & 0,673 \\
\hline
\end{tabular}

Sumber: Data olahan

Hipotesis 2 menguji apakah ERC pada perusahaan yang menggunakan auditor spesialisasi industri lebih tinggi dari pada ERC perusahaan yang menggunakan auditor non spesialisasi industri. Pengujian dilakukan dengan melihat nilai ERC antara perusahaan yang menggunakan auditor spesialisasi industri dan auditor non spesialisasi industri, dan setelah itu dilakukan uji beda independent t-test.

Pengujian dengan menggunakan independent t-test digunakan untuk menentukan apakah dua sampel yang tidak berhubungan memiliki nilai rata-rata yang berbeda.Hasil olahan dari independen $t$-test disajikan dalam Tabel 9 dan 10.

Tabel 9. Rata-rata ERC antara auditor spesialis dan nonspesialis industri

\begin{tabular}{|c|c|c|c|c|}
\hline & $\mathbf{N}$ & Mean & Std.Deviati & $\begin{array}{c}\text { Std.Error } \\
\text { Mean }\end{array}$ \\
\hline$\overline{\text { Dun }}$ & 78 & $-0,0027$ & 0,03715 & 0,00421 \\
\hline 1 & 56 & 0,0054 & 0,04028 & 0,00538 \\
\hline
\end{tabular}

Sumber: Data olahan 
Tabel 10. Hasil olahan independen sample t-test

\begin{tabular}{lcccc}
\hline & \multicolumn{4}{c}{ Levene's Test for Equalityof } \\
& \multicolumn{4}{c}{ Variances } \\
\cline { 2 - 5 } & F & Sig. & t & Sig. (2 tailed) \\
\hline $\begin{array}{l}\text { Erc Equal variances } \\
\text { assumed }\end{array}$ & 0,048 & 0,827 & 1,211 & 0,228 \\
$\begin{array}{l}\text { Equal variances not } \\
\text { assumed }\end{array}$ & & & 1,195 & 0,235 \\
\hline
\end{tabular}

Sumber: Data olahan

Dari analisis pada Tabel 7 dan 8 terlihat bahwa ERC untuk auditor non spesialisasi industri adalah 0,000 dan ERC auditor spesialisasi industri adalah 0,560. Hal ini menunjukkan bahwa ERC pada perusahaan yang mengunakan auditor spesialisasi industri lebih tinggi dibandingkan ERC pada perusahaan yang tidak menggunakan auditor spesialisasi industri

Dari analisis pada Tabel 9 terlihat bahwa rata-rata ERC untuk auditor non spesialisasi industri adalah $-0,0027$ dan rata-rata auditor spesialisasi industri adalah 0,0054. Hal ini menunjukkan ada perbedaan antara ERC auditor spesialisasi industri dan auditor non spesialisasi industri, yaitu rata-rata ERC auditor spesialisasi industri lebih tinggi dari pada auditor non spesialisasi industri.Untuk melihat apakah perbedaan ini memang nyata secara statistik, maka dapat dilihat dalam Tabel 10.

Pada Tabel 10 dapat dilihat bahwa F hitung levene test sebesar 0.048 dengan probabilitas 0.827 . Karena nilai probabilitas $>0,05$ maka dapat disimpulkan bahwa variance populasi dari ERC auditor spesialisasi industri dengan non spesialisasi industri adalah sama. Dengan demikian analisis uji beda ini harus menggunakan equal variances assumed. Nilai t pada equal variances assumed didapat sebesar 1.211 dengan probabilitas 0,228 (two tail). Karena nilai 0,228 > 0,05 maka dapat disimpulkan bahwa rata-rata ERC auditor spesialisasi industri dengan non spesialisasi industri adalah sama.

Hasil pengujian pada hipotesis 2 dapat dilihat bahwa nilai rata-rata ERCuntuk auditor spesialis industri lebih tinggi dari ERC auditor non spesialis industri, dengan nilai signifikansi dibawah 0,05 yaitu sebesar 0,000. Hal ini menunjukkan bahwa secara statistik, ERC untuk auditor spesialis industri lebih tinggi dari auditor non spesialis industri, sehingga hipotesis 2 diterima.Penelitian ini sejalan dengan penelitian Mayangsari (2004) bahwa ERC untuk auditor spesialis industri lebih tinggi dari auditor non spesialis industri. Auditor yang spesialis akan dapat menghasilkan ERC yang lebih tinggi dibandingkan dengan non spesialis. Dengan kata lain dapat juga dikatakan bahwa kualitas earnings yang dilaporkan dipenga- ruhi oleh spesialisasi industri auditor. Penelitian ini juga sejalan dengan penelitian yang dilakukan oleh Balsam et al. (2003) yang menunjukkan ERC perusahaan yang diaudit oleh auditor spesialisasi industri lebih tinggi dari pada non spesialis. Hal ini menunjukkan bahwa pelaku pasar merespon positif perusahaan yang diaudit oleh auditor spesialisasi industri dalam hal kredibilitas pengungkapan laba.

Penelitian yang dilakukan oleh Gramling et al. (2001) menunjukkan bahwa penggunaan auditor spesialisasi industri dapat mengetahui adanya earnings manajemen, kesalahan prediksi dan kemampuan untuk memprediksi arus kas mendatang.Demikian juga penelitian dari Becker et al. (1998) yang menjelaskan bahwa dengan adanya auditor spesialisasi industri dapat mendeteksi earnings manajemen karena auditor spesialis memiliki pengetahuan lebih (superior knowledge) dan tindakan untuk mencegah terjadinya earnings manajemen demi reputasi mereka, sehingga dapat meningkatkan kualitas earnings. Menurut Teoh and Wong (1993), laporan earnings dari auditor yang berkualitas akan lebih akurat dan dapat mencerminkan nilai ekonomi yang sesungguhnya. Secara intuitif besarnya ERC mencerminkan kualitas eanings yang tinggi.

\section{KESIMPULAN DAN SARAN}

Hasil penelitian ini menunjukkan:

1) Spesialisasi industri auditor berpengaruh pada ERC. Hal ini berarti di dalam pengambilan keputusan bisnisnya, investor mengetahui dan mempertimbangkan adanya auditor spesialisasi industri dan auditor non spesialisasi industri. Dengan adanya auditor spesialisasi industri, maka auditor dapat menemukan halhal seperti earnings manajemen, kesalahan prediksi dan kemampuan untuk memprediksi arus kas mendatang. Investor juga merespon positif dengan adanya auditor spesialisasi industri, karena auditor spesialis memiliki pengetahuan lebih (superior knowledge) dan tindakan untuk mencegah terjadinya earnings manajemen demi reputasi mereka, sehingga dapat meningkatkan kualitas laba. Penelitian dari Gramling et al. (2001) membuktikan bahwa laba perusahaan yang diaudit oleh auditor spesialisasi industri mempunyai daya prediksi arus kas mendatang yang lebih akurat dibandingkan dengan auditor non spesialisasi industri.

2) ERC untuk auditor spesialisasi industri lebih tinggi dari pada ERC untuk auditor non spesialisasi industri. Hal ini berarti dapat dikatakan bahwa kualitas earnings yang di- 
laporkan dipengaruhi oleh spesialisasi industri auditor. Hasil perhitungan ERC pada perusahaan yang menggunakan auditor spesialisasi industri memiliki tanda positif, artinya semakin spesialis industri respon investor akan positif, hal ini menunjukkan investor mengerti bahwa penggunaan auditor spesialis industri dapat meningkatkan kualitas earnings.

\section{Saran dan Keterbatasan Penelitian}

1) Rentang waktu untuk pengamatan variabel ERC hanya dari tahun 2006-2010 saja, hal ini dikarenakan karena adanya keterbatasan dalam memperoleh data laporan tahunan untuk periode 2005 kebawah. Untuk penelitian selanjutnya disarankan menambah dengan data laporan tahunan periode 2011 dan 2012 untuk dapat menggambarkan kondisi yang terbaru.

2) Kondisi faktor makro ekonomi yaitu terjadi krisis global pada tahun 2008 yang menyebabkan kondisi pasar modal dalam negeri menjadi labil, diduga dapat mempengaruhi variabel ERC.

\section{Implikasi Teoritis dan Praktis}

1) Hasil penelitian ini diharapkan dapat menjadi bahan referensi penelitian selanjutnya dan sebagai bahan pengembangan riset terutama yang terkait dengan auditor spesialisasi industri dan ERC.

2) Untuk para pengambil keputusan, baik investor maupun kreditor perlu mempertimbangkan bahwa ada faktor-faktor lain yang dapat mempengaruhi ERC, salah satunya adalah spesialisasi industri auditor.

3) Bagi manajer perusahaan, perlu mempertimbangkan penggunaan spesialisasi industri auditor, dikarenakan investor mengerti bahwa penggunaan spesialisasi industri auditor dapat meningkatkan kualitas earnings.

\section{DAFTAR PUSTAKA}

Assegaf, Y.U. (2008). Hubungan Konservatisme Akuntansi dan Earnings Responses Coefficient. Tesis, MM UNS, Surakarta.

Ball, R. \& Brown, P. (1968). An Empirical Evaluation of accounting Income Numbers. Journal of Accounting Research, Autumn.

Balsam, Steven, Khrisnan, \& Yang (2003). Auditor Industry Specialization and Earnings Quality. Tersedia dari: URL: http:/www.papers.ssrn. com, diakses tanggal 13 Juli 2010.
Beaver, W.B. (1968). The Informational Content of Annual Earnings Announcement, Empirical Research in Accounting. Suplement to Journal of Accounting Research, 6, 67-92.

Becker, C.L., Mark, L. DeFond, J.J. \& Subramanyam, K.R. (1998). The Effect of Audit Quality on Earnings Management. Social Science Research Network, 1-24.

Chandrarin, G. (2003). Laba (rugi) Selisih Kurs Sebagai Salah Satu Faktor yang Mempengaruhi Koefisien Respon Laba Akuntansi: Bukti Empiris Dari Pasar Modal Indonesia. Disertasi, Universitas Gajah Mada, Yogyakarta.

Christina, S. (2005). Pengaruh Konservatisme Laporan Keuangan Terhadap ERC. Simposium Nasional Akuntansi, VII, 504-520.

Collins, D. W. \& Kothari, S. P. (1989). An Analysis of Intemporal and Cross-Sectional Determinants of Earnings Response Coefficient. Journal of Accounting and Economics, 1, 143182.

Craswell, A.T., Francis, J.R. \& Taylor, S.L. (1995). Auditor Brand Name Reputation and Industry Specialization. Journal of Accounting and Economics, 20, 297-322.

Dhaliwal, Dan, S., Lee, K.J. \& Fargher, N.L. (1991). The Association Between Unexpected Earnings and Abnormal Security Returns in the Presence of Financial Leverage. Contemporary Accounting Research, 8, 20-41.

Dunn, K.A., Brian, W.M. \& Suzanne, G.M. (2000). Auditor Industry Specialization and Client Disclosure Quality. Social Science Research Network, 1-39.

Easton, P.D. \& Zmijweski, M.E. (1989. Crosssectional variation in the Stock Market Response to Accounting Earning Announcements. Journal of Accounting and Economics, 117-141.

Ekawati, E. (2008). Analisis Faktor-Faktor yang Mempengaruhi Koefisien Respon Laba pada Perusahaan Manufaktur yang Terdaftar di Bursa Efek Jakarta. Jurnal Riset Akuntansi dan Keuangan, 4(2), 100-115.

Ghozali, I. (2008). Aplikasi Analisis Multivariate dengan Program SPSS. Badan Penerbit Universitas Diponegoro, Semarang.

Gramling, A.A., Johnson, V.E. \& Khurana, I.K. (2001). Audit Firm Industry Specialization and Financial Reporting Quality, Working Paper, Georgia State University and University of Missouri-Columbia. Tersedia dari: 
URL: http:/www.papers.ssrn.com, di akses tanggal 13 Juli 2010.

Givoly, D. \& Hayn, C. (2000). The Changing TimeSeries Properties of Earnings, Cash Flows and Accruals: Has Financial Reporting Become More Conservative? Journal of Accounting and Economics,29, 287-320.

Hartono, J. (2000), Teori Portofolio dan Investasi, BPFE.Yogyakarta.

Hogan, C.E. \& Jeter, D.C. (1999). Industry Specialization by Auditors. A Journal of Practice \& Theory, 18, 1-17.

Imhoff, E. \& Lobo, G.J. (1992). The Impact of ex ante Earnings Uncertainly on Earnings response Coefficient. The Accountinf Review, $67,427-439$.

Junaedi, D. (2005). Dampak Tingkat Pengungkapan Informasi Perusahaan Terhadap Volume Perdagangan dan Return Saham: Penelitian Empiris Terhadap PerusahaanPerusahaan yang Tercatat di Bursa Efek Jakarta. Jurnal Akuntansi dan Keuangan Indonesia, 2(2), 1-28.

Kim, Y.H., Willet, R.J. \& Jang, J. (2000). Default Risk as a Factor Affecting Earnings Response Coefficient. Social Science Research Network, 23-45.

Kormendi, R.C. \& Lipe, R. (1987). Earnings Innovations, Earnings Persistence and Stock Return. Journal of Business, 60, 323-345.

Kusharyanti (2003). Temuan Penelitian Mengenai Kualitas Audit dan Kemungkinan Topik Penelitian di Masa Datang. Jurnal Riset Akuntansi dan Manajemen, Edisi Desember, STIE YKPN, 25-34.

Lang, M.H. \& McNichols, M.F. (1990). Earnings Quality, Financial Distress and the Incremental Information Content of Cash Flow". Working paper, Stanford University. Tersedia dari: URL: http:/www.papers.ssrn.com, di akses tanggal 10 Februari 2010.

Lipe, Robert, C. (1990). The Relation Between Stock Return, Accounting Earnings and Alternative Information. The Accounting Review, 49-71.
Mayangsari, S. (2004). Bukti Empiris Pengaruh Spesialisasi Industri Auditor Terhadap Earning Response Coefficient. Jurnal Riset Akuntansi Indonesia, 7(2), 154-178.

Mulyani, S. (2007). Faktor-Faktor yang Mempengaruhi ERC pada Perusahaan yang Terdaftar di Bursa Efek Jakarta. Jurnal Riset Akuntansi Indonesia, 11(1), Juni, 35-45.

Netralia (2007). Pengaruh Spesialisasi Industri Auditor Terhadap ERC. Skripsi, UKSW, Salatiga.

Setyaningtyas, T. (2009). Pengaruh Konservatisme Laporan Keuangan, dan Siklus Hidup Perusahaan Terhadap Koefisien Respon Laba. Fakultas Ekonomi Universitas Sebelas Maret.

Scott, W.R. (2000). Financial Accounting Theory. $2^{\text {nd }} e d$, Prentice Hall Inc. Ontario, Canada.

Suaryana, A. (2007). Pengaruh Konservatisme Laba Terhadap Koefisien Respon Laba. Fakultas Ekonomi Universitas Udayana. Tersedia dari: URL: http:/ejournal.unud.ac.id, diakses 23 Mei 2011.

Teoh, S.H. \& Wong, T.J. (1993). Perceived Auditor Quality and the Earnings Response Coefficient. The Accounting Review, 346-366.

Teets, W.R. \& Wesley, C.E. (1996) "Estimating Earnings Response Coefficient: Pooled Versus Firm-Specific Models", Journal of Accounting and Economics, Vol 21, pp.279-295.

Widhiarso, W. (2011). Analisis Data Penelitian Denagn Variabel Kontrol, [Dikutip 9 November 2011]. Tersedia dari: URL: http:/widhiarso. staff.ugm.ac.id, diakses 2 Januari 2011.

Zhou, J. \& Elder, R. (2001). Audit Quality and Earnings Management by Seasoned Equity Offering Firms. Asia Pasific Journal of Accounting and Economics, 11, 95-120. Tersedia dari: URL: http:/ejournal.unud. ac.id, diakses 23 Mei 2011.

Zulhwati (2005). Pengaruh Pemerataan Laba Terhadap Kualitas Laba. Jurnal Akuntansi. Manajemen dan Sistem Informasi, 2, 194-205. 